Indonesian Journal of EFL and Linguistics

Vol. 6 No. 1, 2021

eISSN: 2503-4197, pISSN: 2527-5070

www. indonesian-efl-journal.org

doi: http://dx.doi.org/10.21462/ijefl.v6i1.347

\title{
Focus on Form and Focus on Forms in Implicit Grammar Teaching Strategy
}

\author{
Rizki Indra Guci \\ Universitas Sebelas Maret \\ e-mail: rizkiindraguci@student.uns.ac.id \\ Dewi Rochsantiningsih \\ Universitas Sebelas Maret \\ e-mail: dewi_roch@staff.uns.ac.id \\ Sumardi \\ Universitas Sebelas Maret \\ e-mail: sumardi74@staff.uns.ac.id
}

\begin{abstract}
:
Grammar instruction in foreign language teaching has been identified by most studies as one aspect that plays an important role in promoting the learning process of reading, writing, speaking and understanding a foreign language. Consequently, secondary and foreign language teaching of grammar is seen as a topic of debate. So academics and teachers seem to have been willing to work out the proper way of teaching grammar. This condition contributes to a likely cause of uncertainty for teachers and students, and then brings researchers to a rigorous theoretical discussion on the question of how grammar should be presented: explicitly or implicitly. The purpose of the present case study was to gather information into the implementation of the implicit grammar teaching strategy enrolled in senior high school. To this extent, interview sessions and observation were used to obtain all the data required for the study. The results, in a broad sense, confirmed that the teacher showed positive views on the implementation of the implicit grammar teaching
\end{abstract}


Rizki Indra Guci, Dewi Rochsantiningsih, Sumardi

strategy. However, classroom practices were quite different from the findings of previous related research consistent with the supremacy of either Focus on Form or Focus on Forms in the delivery of lesson materials. As an implication, this study encouraged Indonesian English teachers to start considering the implementation of implicit grammar teaching strategy so that students could be directed to the language acquisition cycle instead of the language learning.

Keywords: foreign language teaching, grammar instruction, implicit teaching

\section{INTRODUCTION}

Grammar instruction is seen as a long-lasting topic of debate. Scholars and teachers seem to have been eager to figure out how to teach grammar ideally. Subsequently, grammatical considerations contribute to various approaches (Nazari, 2013). Thus, there is a major gap in research between FonF (Focus on Form) and FonFs (Focus on Forms) approach. As per Burgess \& Etherington (2002), Focus on Forms represents a constructivist view of language that focuses on form rather than meaning. Focus on Form, on the other hand, implies leading learners to grammatical elements within such a communicative context.

In line with those, theorists who favor the explicit method of grammatical instruction are inclined to explicitly teach grammatical structures and rules for the organization of linguistic elements necessary for communicative purposes in the target language (Schmitt \& Zimmerman, 2002; Taylor et al., 2009). Contrarily, some academics who are driven by an implicit approach claim that foreign language students would be ready to 'naturally' develop all the grammar skills needed to communicate effectively through exposure to understandable and meaningful linguistic input (Scott, 1989).

Commonly, teachers in EFL classrooms across the world can have both implicit and explicit instruction. They offer certain guidance to students and make concerted efforts to learn when applying explicit teaching (Talley \& Hui-Ling, 2014), that in turn would allow learners to obtain knowledge into the implemented learning strategies, to learn about using the new methods to practice the target language, to self-evaluate the strategies utilized and also the information transferred to new task. By comparison, the implicit teaching strategy is designed to offer students the ability to understand without recognizing what they have learned Talley \& Hui-Ling, 2014). It has been shown that implicitly instructed learners are able to develop their comprehension of language rules (Griffiths, 2003). The natural approach theorists, Krashen and Terrell (1998) therefore perceive explicit grammar teaching and error correction as non-essential elements of instruction in foreign languages. 
They argued that when teachers focus exclusively on grammatical forms, communicative purposes, as well as learners' fluency, will be hampered. That being said, if teachers merely emphasize the meaning, students will not be sufficiently accurate in the real context of the proper use of language (Farshi \& Baghbani, 2015).

There are some previous studies (Başöz, 2014; Gheisari \& Yousofi, 2016; Graus \& Coppen, 2016; Lichtman, 2013; Tammenga-Helmantel et al., 2014; Uysal \& Yavuz, 2015) that investigated the implementation of English grammar teaching and learning. According to several previous studies, there were numerous researches focusing on the perceptions about grammar along with the preferences for the type of grammar instruction (e.g., inductive and deductive). On the other hand, there is a limited number of studies specifically investigating implicit teaching strategies on grammar instructions. Thus, as research objectives, the researcher anticipated that the way in which teachers consider grammar teaching and learning processes in regards to implicit teaching strategies, as well as the way in which teaching has been applied, could be defined in detail by conducting this case study. In particular, the researcher also expected that the causes of the broad difference of the implementation of the implicit and explicit teaching strategy could be clarified by this study.

\section{LITERATURE REVIEW}

\subsection{Implicit Teaching}

For many areas of the second and foreign language, such as knowledge, instruction, and learning, the terms "implicit" and "explicit" may apply. Implicit knowledge of the language is seen as something that can be reached without any consciousness, in time-pressed circumstances, with an emphasis on meaning instead of form, and without the use of meta-language (Ellis, 2005). Likewise, Ling (2015) identifies implicit teaching of grammar as a teaching method which suggests that learners must naturally comprehend the language with the aid of the situational scene in grammar learning. It is also often identified as a suggestive method, mainly by adopting the inductive approach and using language in communication. Learners are mainly guided to concentrate on English through the introduction of communication scenes. Such teaching method appears to represent the theory of communicative teaching, emphasizing the students' unconsciousness, abstractness, and automated learning of grammar.

Furthermore, Ellis (2005) claimed that different forms of tasks can be used separately to acquire implicit and explicit knowledge: time-pressed, meaningfocused exercises (e.g. oral phrase imitation, oral story retelling, and timed grammatical evaluation tests) trigger implicit knowledge, and unpressed, formfocused assignments (e.g. untimed grammatical assessment and metalinguistic knowledge) entail explicit knowledge.

Indonesian Journal of EFL and Linguistics, 6(1), 2021 


\section{Rizki Indra Guci, Dewi Rochsantiningsih, Sumardi}

In the school, the features of implicit and explicit language instruction are close to those of assignment design addressing implicit and explicit knowledge. Implicit instruction is presented spontaneously in communication-oriented practice, is discreet (minimum interference of meaning communication occurs), introduces target forms in context, does not require the use of meta-language, and encourages the free use of the target form (Housen \& Pierrard, 2005).

\subsection{FonF (Focus on Form) and FonFs (Focus on Forms)}

Long (1991) offered a more comprehensive classification of the broad, explicit and implicit distinction: Focus on Form and Focus on Forms. In the claim that the teaching of form must be integrated into principally substantive lessons, he describes the "Focus on Form" as an approach that promotes students' focus to linguistic elements as they arise unexpectedly in lessons focused primarily on meaning or communication (Long, 1991). It constructively introduces grammar with a taskbased syllabus and facilitates learners a slower process to understand the form through the use of natural language. However, it is important for them to learn from the assignments or "real-world uses to interact to which the L2 puts outside the class" (Long, 2016).

Alternatively, Focus on Forms represents a discrete approach. It relies on traditional, structural syllabus-based lessons and involves the introduction and practice of distinct grammatical items (Long, 1991). In addition, he explained that the Focus on Forms does not rely on any kind of need analysis, frequently uses non-authentic language models containing poor communication practices, and in turn does not pay close attention to natural language acquisition sequences (Long, 2016).

After all, it is not always simple, uncommunicative, and pre-planned to teach grammar in separation to the other language skills. Ellis (2016) has reasonably claimed that even a formal (structural) syllabus can provide communication materials in grammatical instructions. As described in Murtisari, Hastuti, \& Arsari (2019), it is also necessary for us to note that Ellis (2016) also stressed that FonF/FonFs is not restricted solely to grammar but are also applied to other linguistic aspects. In particular, grammatical rules can also be presented and preplanned to explicitly focus on form instructions while implicitly and consciously focusing on forms. As far as that condition is concerned, Ellis (2016) had a more functional concept of Focus on Form, which applies to "various strategies designed to attract the attention of the student when using L2 as a medium of communication,' and the Focus on Forms is known to be 'various devices (which include 'exercises') meant to focus the attention of learners on specific forms as particular study items.' Accordingly, Doughty and Williams (1998) suggested that Focus on Form and Focus on Forms could not be regarded as two opposing sides. The key component of the differences is "Focus on Form tends to focus on formal language aspects, while Focus on Forms is limited to such a focus". They believe that the key feature of Focus on Form (FonF) is that the meaning and use must be 
discussed before students become aware of the linguistic form being used to convey meaning (Doughty \& Williams, 1998).

As a result, FonF is preferred for several reasons. First, it is considered to be undertaking more natural stages of language acquisition, and learners are also supposed to notice when they are introduced to realistic language use (Long, 1998). The fostering of authentic language skills through Focus on Form, in addition, concerns further exposure to communication-related activities (Doughty, 2001). In addition, Ellis (2015) indicated that FonF improves not only fluency but also accuracy by providing learners corrective input in their efforts to communicate. Similarly, practitioners of implicit teaching such as Celce-Murcia (2001), Gass (2012), Krashen (1994), and Nagy and Herman (1987) argue that there is no need for explicit instruction because adequate exposure to target language inputs and sequences will lead to the analysis of the required components.

There are also some drawbacks in such an integrative approach, despite the benefits listed above. For example, Poole (2005) reported that grammar instruction should be undertaken more thoroughly, taking into account that students appear to be more concentrated on vocabulary than grammar. He also mentioned that in most cases, particularly in developing countries where classes are usually overcrowded, Focus on Form, which requires relatively small classes, well-trained instructors, and a high degree of student participation, is difficult to perceive. Moreover, it does not tend to appeal to groups that have already been favored to issues that are collaboratively and teacher-centric. In spite of the numerous disadvantages, scholars who favor an implicit approach suggest that all the grammar skills required to interact effectively from exposure to comprehensible, substantive linguistic input would "naturally" be developed. Krashen's differentiation between "learning" (a conscious process) and "acquisition" (a subconscious process) is the foundation of his concept of implicit teaching strategies (Krashen, 1983). He assures that the learning of a second language can occur in the classroom without any explicit study of grammar if the students are exposed to sufficient, understandable information. Obviously, he points out that the explicit study of grammar does not develop anything in the natural acquisition process: “... grammar exercises ... can be valuable as tools to encourage learning. Nevertheless, it should be taken into consideration that while their function is essential, there will be very little acquisition during their use" (Krashen \& Terrell, 1983).

In the same way, Terrell identifies the distinction between learning and acquisition in his theory of the natural approach. The basic principles for this approach encompass focusing on content rather than form, attempting to engage students in all target language components from the start, making revisions to written work only, and encouraging the "pre-speaking phase" during the initial stages of the exposure until students are able to respond in the target language (Krashen \& Terrell, 1983). In addition, implicit teaching involves 'learning taking place without awareness or 
intentionality' (Ellis, 2008). Implicit learning relies on exposure (input) and contacts with more experienced speakers, a philosophy focused on first-language acquisition.

In refers to the two parties mentioned earlier, several other researchers have found that a combination of both implicit and explicit language teaching strategies can promote students' performance (Hunt \& Beglar, 2005). However, Ellis (2015) points out that all of the above-mentioned forms of teaching grammar are complementary and also maintains that "they should not be treated as oppositional." As per Ellis (2015), who has published various studies on FonF and FonFs, argued that both approaches are essentially equivalent. Thus, the two approaches to grammar teaching and learning should not be interpreted against one another.

\section{RESEARCH METHODOLOGY}

This research was a case study, which is defined by Ary, et al (2010) as single unit research to provide a rich and holistic, in-depth analysis. It is consistent with McMillan (2008) who claimed that the case study was an in-depth review of one or more events, cultures, social classes, individuals, or populations using qualitative methods to gather data and provide a detailed description. Similarly, Yin (2003) pointed out that the case study would monitor events or frequencies over time, rather than simply. Therefore, the nature of the case study was selected as the most suitable way to resolve the research questions. The present research used descriptive methods, that is, a methodology used to describe the status of a group of individuals, an individual, a situation, a thinking system, or events in the present.

\subsection{Participants}

Regarding the research questions on the implicit teaching strategies implementation, the focus of this research was on English teachers in the secondary level of school. In addition, as the research case, the competent English teacher chosen was the one who teaches English and implements this teaching strategy.

This study included one Indonesian teacher at DKI Jakarta, Indonesia, who teaches English at the International Islamic Integrative School. The participant was chosen on the basis of the basic theory of the purposive sampling technique with the following conditions: First, she was adequately competent on the basis of her degree of English proficiency. Second, she had vast knowledge of teaching and learning English. Third, the implementation of the implicit teaching strategy has rarely been applied in Indonesian state schools and has also been seen as a new teaching strategy to be employed in the sense of English teaching and learning in schools. As a result, it was not possible for the researcher to increase the number of participants. Fourth, she was willing to be participating in this research.

\subsection{Data Collection and Analysis}

All data in this research were collected by using in-depth interview and observation focusing on the issues relevant to the implementation of implicit grammar teaching 
strategies. The in-depth interview sessions were held from August 28 ${ }^{\text {th }}, 2020$ up to October $2^{\text {nd }}, 2020$, based on the spare time of the participant. The observation was then held from February $9^{\text {th }}, 2021$ up to February $19^{\text {th }}, 2021$ to view the practice of English teaching by implementing implicit teaching strategies on grammar instruction. To analyze the data, the researcher used the interactive data analysis model by Miles, Huberman, \& Saldana (2020) which consists data collection, data condensation, data display, and drawing and verifying conclusion.

\section{FINDINGS}

\subsection{The Implementation of Implicit Teaching Strategy}

Grounded on the participant's responses, the researcher could come up to this part of study findings. To sum up, there were varied points highlighted by the researcher to provide the answer of the research question. The following transcripts and the brief explanation were presented to depict the teacher's answers.

Interviewer : How do you implement the implicit teaching strategy on grammar instructions in relation to the integration of English language skills?

Teacher : For the first example, it is related to teaching writing. I never ask my students to write certain sentences or texts using particular tenses. I would rather ask them to write a text-based on certain topic or theme, such as personal experience. By doing that, they will automatically involve particular tenses in composing their texts. Afterward, when I have to give a unit test in writing class, I never instruct them to write a number of sentences based on certain tenses like "write down five sentences using the simple past tense..." Then, after they submit their assignments, I will check the grammar used in their writings, whether or not the tenses are written correctly.

Based on the above transcripts, the teacher highlighted the implementation of implicit grammar teaching in relation to writing teaching and learning. The point of her statement was that she never gave students a conventional kind of instruction, namely composing a number of sentences using particular tenses. Instead of focusing on the structural forms, she preferred to direct the learners to write based on certain theme or topic. She believes that such activities could help them familiarize into English grammar by focusing on meaning instead of the particular forms. As the assessment phase, she also gave a similar kind of instructions. Afterward, she would check the grammar used by the students, whether or not the grammatical items were used appropriately. The next point is about the implementation of implicit grammar teaching in relation to reading skills, the following transcript was chosen to represent the teacher's response.

Indonesian Journal of EFL and Linguistics, 6(1), 2021 
Rizki Indra Guci, Dewi Rochsantiningsih, Sumardi

Teacher : When it comes to teaching reading skills, I never start my class by determining what kind of text to discuss in order to include certain grammatical items. Thus, I never begin by saying introductory sentences such as "today we are going to learn about descriptive text..." or something like that. Instead, I prefer to go straight to the content of the text and explain things like how an article should be written. For example, I tell my students that an article at least starts with introductions, arguments or descriptions, and then conclusions. Because when they have to read a text, they will find patterns that are more or less the same regardless of the type of text. After that, at the end of the lesson, I give them some questions related to reading comprehension. So, what I emphasize is more about the theme or meaning of the text they read instead of the form. However, I still implicitly provide some kind of highlights on necessary grammatical items, such as noun phrases, adjective clause, etc. In this way, the students can unconsciously interact with various grammatical items or meta-language related to the theme of the text being discussed.

In accordance to the transcripts above, it could be concluded that the teacher's main focus in teaching reading is quite similar to the ones in writing. She decided not to begin the reading class by explicitly telling students the type of text being learned. Thus, as the beginning, she preferred to present the so-called common generic structures of a text. After that, they discussed about the idea of the text chosen as the learning material. She also implicitly included the related grammatical items so that the students could understand the necessary meta-language items without fully realizing that they do. And as the evaluation, she provided a number of reading comprehension tasks to finish. Next, the process of teaching speaking skills in relation to implicit grammar teaching is included in the following transcript.

Teacher : Next, when it comes to speaking, I usually invite the students to discuss certain topics. For example, we once talked about fashion. I asked their opinion on fashion, and then when they were explaining their points of view, I assessed whether the grammar they used was correct or not. And after they finished talking, I told them what was wrong or needed to be improved, not to interrupt while they were still talking. Because, in my opinion, if I interrupt the conversation, it can sometimes lower their self-confidence, make them lose focus, etc. Apart from that, I also ask my students to have a conversation in pairs or small groups about certain topics, such as personal experiences, holiday activities, and so on. In addition, I sometimes show them a number of pictures, and then I give some related clues and questions. While they are talking 
about the pictures, I will be listening and taking notes on few things related to the grammatical items.

As shown above, the teacher preferred to immerse the students into the English language environment by discussing about certain topics in pairs or small groups. Besides, she also applied the picture-cued tasks in teaching speaking, which means she prepared particular pictures to talk about in speaking class. In addition, she also claimed that she would rather use the minimum interruption of meaning communication in speaking class instead of interrupting the students' conversations or explanations. She believed that such disruption might affect their focus and selfconfidence. Therefore, the assessment of grammatical items was given at the last session. Thereafter, the last English skill to be integrated into the implicit teaching, listening skill, was described by the following transcript and explanation.

Teacher : For Listening, I usually show a video of people having a dialogue, and after that, I ask the students to retell what they have seen. So, it can be said that the listening and speaking activities that I implemented relate to one another. Apart from that, I usually integrate listening activities with writing. So, after playing a video in class, I ask the students to retell what they had watched by writing down the story.

As regards the above transcript, the process of teaching listening was integrated into speaking and writing skills. The teacher chose to start the listening class by playing a video of some conversations, and then she involved the use of narrative retelling technique to check whether or not the students understand the video content. Such assignment was also used by the teacher to assess their understanding of the grammatical items or meta-language aspects included. After all, the teacher shared her experience in handling the students who were still having problems in understanding the materials. The response is as follows.

Interviewer : What did you do if there were students who still had problems in understanding the materials at the end of the teaching and learning process?

Teacher : In case there are some students who do not understand or still make many mistakes, this is the time when I provide them the socalled enrichment sessions by explicitly explaining the related material. This is why we have to admit that sometimes we still need to employ explicit teaching, and we cannot get rid of it. In addition, some students also still find it difficult to understand the implicitly presented materials. For example, in my class, not all of them have the same English proficiency because some students are the ones moving from the public school to our place, international school. So, considering that most of the transferred students have 
previously been used to explicit teaching and learning, I decided to give them a slightly different treatment. In that sense, for just a few initial meetings, I will provide additional explanations regarding the meta-language they need to know, but after that, I will continue the teaching and learning process by implementing the implicit teaching strategies so that they will no longer depend on the understanding of the form of a language, but the meaning.

According to the transcripts above, the teacher claimed that it would not be a good decision for the teachers to completely get rid of explicit teaching. Instead of treating explicit and implicit teaching strategies as two polar ends, she prefers to combine both strategies in class. Furthermore, she claimed that there were still some students who could not understand the lessons because of some factors, namely language proficiency and learning habit. Therefore, explicit teaching was still needed to facilitate the students in the enrichment sessions. However, the teacher emphasized that implicit teaching is still chosen to dominate the teaching and learning process, and the students are asked to get themselves used to such teaching strategy.

In addition, from the results of observation, there were a number of strategies possessed by the teacher in implementing the implicit grammar teaching strategies in the process of English teaching and learning. The following conceptual table was made to display the overall condition of the data, and a complete elaboration to illustrate the data were also provided.

Table: 1 The implicit teaching strategies possessed by the teacher on Grammar instructions

\begin{tabular}{|c|c|c|c|}
\hline Teaching Strategies & Language Skills & $\begin{array}{l}\text { Language } \\
\text { Elements }\end{array}$ & Teaching Stages \\
\hline \multirow{2}{*}{ Oral narrative retelling } & Speaking & \multirow{2}{*}{ Grammar } & \multirow{2}{*}{ Main activity } \\
\hline & Listening & & \\
\hline Narrative retelling & Writing & Grammar & Main activity \\
\hline \multirow{3}{*}{$\begin{array}{l}\text { Timed grammaticality } \\
\text { judgment testing }\end{array}$} & Speaking & Grammar & Main activity \\
\hline & \multirow{2}{*}{ Writing } & \multirow{2}{*}{ Grammar } & Main activity \\
\hline & & & Closing \\
\hline Picture-cued task & Speaking & Grammar & Main activity \\
\hline Project-based learning & Speaking & Grammar & Main activity \\
\hline
\end{tabular}

Based on the above table, there were five teaching strategies employed by the English teacher in order to implement the implicit grammar teaching in class. The two of them were in line with the strategies based on the theory by Ellis (2005), namely oral narrative retelling and timed grammaticality judgment testing. Meanwhile, the other three additional strategies were managed to be included by the researcher based on the response of the participant in the interview along with the 
teaching practice observed; they were narrative retelling, picture-cued tasks and project-based learning. In regards to the principle of an implicit teaching strategy which is intended to offer the student a chance of learning without realizing what they have learned (Talley \& Hui-Ling, 2014), the teacher did not provide any certain time or meeting to discuss about grammar with the students in class. To that end, she implicitly integrated grammar teaching to the teaching and learning activities of major English skills, such as speaking, listening, and writing.

The first teaching strategy possessed by the teacher was an oral narrative retelling, which in the application was involved in the main activity of teaching and learning process of speaking and listening skills. However, the implementation of oral narrative retelling done by the teacher was apparently integrated to the second strategy named narrative retelling, which involved the main activity of writing teaching and learning. The teacher chose to start the listening class by playing a video of some conversations, and then she involved the use of both narrative retelling strategies to check whether or not the students understand the video content.

The next strategy was timed grammaticality judgment testing which was involved in the teaching and learning process of speaking, listening, and writing skills. This strategy was implemented by instructing the students to answer several questions or telling them to write down particular passages in certain time limit. Based on the observation, the teacher employed this strategy in the main and closing activity of the teaching process involving speaking and writing skills. The teacher showed a slide containing several questions about "prepositions" and asked students to answer them. There were two parts of questions that had to be finished, the first part was done orally, then the second was finished by the students in written form. In addition, the teacher also applied this strategy as the closing activity in a teaching process involving the writing task in which she instructed the students to write down the texts based on a certain theme in an adjusted time limit. Afterward, she would check the grammar used by the students, whether or not the tenses or other grammatical items were used appropriately.

The next strategy was a picture-cued task which was involved in the teaching and learning process of speaking. The teacher applied such strategy in teaching speaking by preparing particular pictures along with the related clues and questions to be discussed, and while the students were explaining the pictures or answering the questions, the teacher was listening and assessing the use of grammatical items. The last strategy was project-based learning, in which the teacher instructed the students to do a presentation about movie characters review and asked the remaining students to give some questions at the end of each presentation. Thus, there were conversations taken place among the teacher and students in the question-andanswer sessions involving the use of certain related grammatical items. 
Rizki Indra Guci, Dewi Rochsantiningsih, Sumardi

\subsection{The Obstacles in the Implementation of Implicit Teaching Strategy}

There were varied obstacles in implementing the implicit teaching strategy on grammar instructions shared by the teacher, namely the overcrowded class, the syllabus used, course books, etc. The following transcripts and brief explanations are properly presented to depict the response.

Interviewer : Do you think that the overcrowded class could be the disadvantage in implementing the implicit teaching strategy?

Teacher : I think the number of students in each class could be one of the factors leading the teachers prefer to implement explicit rather than implicit teaching strategy. Because, as the comparison, there are only about ten children at most in each class in international school I teach. So, when I teach them implicitly, in this case, by increasing the communication activities, I can do it more freely. In fact, I can also have a dialogue with the students one by one so that the communication can be better and more intense. Meanwhile, I doubt that I could do the same thing in public schools, regarding a large number of students, sometimes there are even more than thirty students in one class. However, regardless of the number of students who are considered overcrowded in each class, I think this should not make the implementation of implicit teaching impossible. In my opinion, the implicit teaching strategy can still be implemented by combining it with the explicit. By that, students are expected to gradually get used to implicit learning, regardless of whether the portion of the teaching strategy is more explicit than implicit or vice versa.

Based on the above transcripts, the teacher agreed that the number of students in the class could impact the implementation of implicit teaching strategy. Furthermore, she emphasized that it would not be easy to have such intense communication with the students in order to build and immerse them into a better language environment. However, she added that it should not make the implementation of implicit teaching impossible. In order to cope with such an issue, she suggested that the teachers could try to combine explicit and implicit teaching in class instead of merely teaching explicitly. The next possible obstacle is discussed on the following transcript.

Interviewer : Do you think that the syllabus used by the teacher could impact the implementation of implicit teaching strategy?

Teacher : In my point of view, based on my past experience teaching in public schools, I found that there were differences in their syllabus. In the syllabus used in public schools, especially in the grammar section, there is a certain part where teachers are directed to convey particular grammatical items, and there is often additional 
information in the form of structural forms or sentence patterns. Meanwhile, at this international school, the syllabus we use is different since it does not have any explanation of what grammatical items should be taught and so on.

As shown on the above transcript, the teacher highlighted on the comparison between the contents of syllabus of international and public schools. She claimed that certain part of public school's syllabus, the explanation of particular grammatical items and sentence patterns, makes it tricky for the teachers to not to discuss about such learning materials explicitly. Afterward, this kind of structural syllabus in turn affects the course books used by the school as discussed in the transcript below.

Interviewer : Do you think that the course books used by the teacher could influence the implementation of implicit teaching strategy?

Teacher : Yes, I do think so. Our course books look quietly similar to the syllabus used in school. Because, based on my experience teaching in public schools, the textbooks they use mostly include structural forms or meta-language aspects needed in each chapter. Meanwhile, in textbooks used in international schools, additional information in the form of structural forms or aspects of grammatical items will be found at the last part of the book, some textbooks do not even provide such a thing. In public schools' textbooks, it is common thing for us to find some explanations of patterns or structural forms of certain tenses. Meanwhile, in international schools, we will only find examples or texts as well as a number of questions used as the assignments. In addition, public school textbooks are mostly attributed with specific explanations of text types studied in the chapter, their generic structures as well as language features. Meanwhile, international schools' textbooks only present the contents of the text and the reading comprehension questions as the exercises.

In accordance to the transcript above, she put the focus on the comparison between the contents of course books used in international and public school. She stated that the materials such as structural forms and other grammatical items, as well as generic structures and language features in the discussion of certain text type, which are included in public school text books might be inevitably leading the students to explicitly learn about the meta-language aspects. Afterward, the next possible obstacle was related to the educators as discussed below.

Interviewer : Do you think that the needs of well-trained educators could be the obstacle in implementing the implicit teaching strategy?

Indonesian Journal of EFL and Linguistics, 6(1), 2021 
Rizki Indra Guci, Dewi Rochsantiningsih, Sumardi

Teacher : I think this is more about the facilities or tools provided by the school. In my school, the media provided are the ones that really support me in implementing the implicit teaching. Meanwhile, in public schools, what their teachers get encourages them to be used to implementing explicit teaching strategy. Starting from the syllabus, textbooks, and so on. In addition, the school I work for also regularly holds seminars or training about implicit teaching strategies for the teachers.

As regards the above transcript, the teacher stated that it was not completely about the well-trained educators, but the facilities provided by the stakeholders, namely syllabus, textbooks, etc. She also added that the implicit teaching implementation she has been doing could be made possible by the supporting facilities she got. Simply put, different tools might lead the teachers to implement different teaching strategies. Furthermore, the next possible obstacle was as follows.

Interviewer : Do you think that the learners' participation in class could influence the implementation of implicit teaching strategy?

Teacher : In my opinion, the level of students' participation in learning at the public schools I taught and the international school where I teach today are different, especially in English class. Because in this international school most of the students already have sufficient English proficiency, although not all of them come from abroad. So, automatically, they can build a better learning atmosphere without any significant obstacles related to language barriers. Meanwhile, when I was in public school, I could not teach my students by fully talking in English since some of them find that difficult to follow. And sometimes, some students even asked me to explain the material using the Indonesian language. However, I am not saying that all students in public schools have low English proficiency, because there are still students who are good at it.

Based on the above transcripts, the teacher stressed upon the varied level of students' language proficiency which in turns possibly create the language barrier. She added that it was not really difficult to apply the implicit teaching in an international school since most students are considered to have good English proficiency. Meanwhile, she admitted that it could indeed be challenging to teach implicitly in public schools, regarding the varied English proficiency. Additionally, the last possible difficulty was represented by the transcript below.

Interviewer : Based on your experience, is there any other obstacle in implementing the implicit teaching strategy on grammar instructions? 
Teacher : Another obstacle is that some learning materials about grammatical items are expected to be completed more quickly if it is taught explicitly. But of course, that is not what we are achieving in the teaching and learning process. So, I would rather keep implementing the implicit teaching strategy, although it will take a relatively longer time.

In accordance to the above transcript, the teacher highlighted the duration taken for certain lesson materials. She said that some topics about meta-language or grammar items were undeniably simpler to be explained in the explicit way rather than implicit. However, she argued that teaching is not all about getting things done as quickly as possible.

\section{DISCUSSION}

Grounded on the study findings, the researcher concluded that: (1) The implicit and explicit teaching strategy could not be completely treated as two polar ends; (2) The implementation of implicit teaching strategy could be done by both FonF (Focus on Form) and FonFs (Focus on Forms) approach; (3) There were some possible obstacles influencing the implementation of implicit teaching strategy on grammar instructions.

Furthermore, the teacher's viewpoints are somehow in line with the principle of implicit teaching strategy by Ling (2015). The implicit teaching of grammar is referred to the method of teaching which emphasizes that students must acquire the language naturally by the help of situational scene in learning grammar. It is also defined as a suggestive method, largely by employing the adaptation of an inductive way of thought and by the use of the language in communication. Thus, this method of teaching reflects the communicative way of teaching, stresses upon the students' unconsciousness, abstractness, and automation of grammar learning. In addition, the teacher's response also supported the theory by Housen \& Pierrard (2005), the implicit instruction is given spontaneously in communication-oriented activities, is unobtrusive (minimum interruption of meaning communication happens), introduces target forms in context, makes no use of meta-language, and promotes free use of the target form. However, both two teaching strategies, explicit and implicit, could not be completely separated. As the teacher stated previously, it would not be a good decision for the teachers to completely get rid of explicit teaching. Thus, instead of treating explicit and implicit teaching strategy as two polar ends, she preferred to combine both strategies in class. To that end, the teacher involved explicit teaching in facilitating the students in the enrichment sessions.

Another focus shown in the response given by the teacher as well as the teaching practice in relation to the approach used in the implementation of implicit grammar teaching, the study findings indicated that she completely agreed to the definition of FonF (Focus on Form) and FonFs (Focus on Forms) suggested by Ellis (2016). FonF 


\section{Rizki Indra Guci, Dewi Rochsantiningsih, Sumardi}

is considered to pertain to "varied techniques aimed at getting the attention of the learner to form while using L2 as the tool of communications", while FonFs is defined as "different devices (including 'exercises') designed to set the students' focus to learn about some particular forms as the specific objects of the study". Therefore, she employed both approaches, FonF and FonFs, in implementing the implicit teaching strategies. By this, it means the teacher did not treat FonF as the one specified for implicit teaching only while FonFs for explicit teaching. Instead, the teacher combined FonF and FonFs in implementing the implicit teaching and agreed not to treat the two approaches against each other.

As what normally happened to any other teaching strategies, the teacher still needed to cope with several issues which were partly in line with Poole (2005). They were the number of students in one class which could lead to the overcrowded classroom and the varied level of students' language proficiency which influenced the learner involvement in the teaching-learning process. Nevertheless, she did not agree with Poole's point about the well-trained teachers. She claimed that it was more about the provided school facilities and stakeholders' policies. Because, from her point of view, no matter how good the teachers are, they would still not be able to implement implicit teaching strategies if the facilities (e.g., syllabus and course books) provided and policies taken by the schools primarily supporting the implementation of explicit teaching. Additionally, she said that the duration is taken for certain materials somehow also affected the success of implementing such teaching strategy, since some of them might be easier and simpler to be presented explicitly.

\section{CONCLUSION}

From the results of the study, it appears that the teacher showed positive viewpoints about the implementation of implicit teaching strategy on grammar instructions. Regarding the teaching and learning process, in relation to the integration of four major skills in English language skills, she decided to dominate the teaching process with the implementation of implicit teaching. In that way, she claimed that her students could put their focus on meaningful communication instead of the structural form. However, she argued that, although the implicit teaching strategy seems favorable, it does not mean that the teachers could get rid of the explicit teaching strategy at all. Additionally, she agreed that it would be nice if the teachers could combine the explicit and implicit teaching strategy, considering that they sometimes still need to implement the explicit in order to cope with several obstacles in the Indonesian international school context. Furthermore, the overall discussion about FonF (Focus on Form) and FonFs (Focus on Forms) approach lead some scholars to perceive that FonF is merely attributed to implicit teaching, while FonFs is for the explicit. In fact, based on the response given by the teacher as well as the teaching practice being held, the researcher could come into the conclusion that both approaches could be involved in implementing the implicit teaching strategy. Besides, the teacher could combine them so that the language skills integration 
might be made possible. Nevertheless, amid the advantages of the implicit teaching strategy, there were still a number of obstacles that the teacher had to cope with. Moreover, regarding the lack number of the implementation of implicit teaching in Indonesian public schools, the teacher claimed that there were some possible factors influencing such condition, such as the overcrowded class, the syllabus and course books used, level of learners' participation, as well as the needs of extra time of teaching and learning process.

Thus, as a suggestion, the teachers are expected to start considering the implementation of implicit grammar teaching strategy, so the students could be guided to the cycle of language acquisition instead of language learning. In addition, the school stakeholders should support the teachers with the teaching facilities they need in implementing implicit teaching strategy, so the language environment could be set by the teacher without any significant obstacle involving the lack of support of teaching media or tools. Finally, for further researchers, there are still numerous areas to be explored and studied in terms of the implementation of implicit grammar teaching strategy, especially in the application of such strategy in a broader context of Indonesian international and public schools. Studies remain scarce and the researcher encourages future quantitative along with qualitative studies in such fields to increase scientific treasures.

\section{REFERENCES}

Ary, D., Jacobs, L.C \& Sorensen, C. (2010). Introduction to Research in Education, Ed. 8, United States of America: Wadworth.

Başöz, T. (2014). Through the eyes of prospective teachers of English: Explicit or implicit grammar instruction? Procedia - Social and Behavioral Sciences, 158, 377-382. https://doi.org/10.1016/j.sbspro.2014.12.103

Burgess, J., \& Etherington, S. (2002). Focus on grammatical form: Explicit or implicit? System, 30(4), 433-458. https://doi.org/10.1016/S0346251X(02)00048-9

Celce-Murcia, M. (2001). Teaching English as a second or foreign language. Boston, MA: Heinel \& Heinel.

Doughty, C. (2001). Cognitive underpinnings of focus on form. In P. Robinson (Ed.), Cognition and second language instruction (pp. 206-257). Cambridge: Cambridge University Press.

Doughty, C., \& Williams, J. (1998). Focus on form in classroom second language acquisition. Cambridge, UK: Cambridge University Press.

Ellis, R. (2005). Measuring implicit and explicit knowledge of a second language: A $\begin{array}{llll}\text { psychometric } & \text { study. } & \text { SSLA, } & \text { 141-172. }\end{array}$ https://doi.org/10.1017/S0272263105050096

Ellis, R. (2008). The study of second language acquisition (2nd ed.). Oxford: Oxford University Press. 
Rizki Indra Guci, Dewi Rochsantiningsih, Sumardi

Ellis, R. (2015). The importance of focus on form in communicative language teaching. Eurasian Journal of Applied Linguistics, 1(2), 1-12. https://doi.org/10.32601/ejal.460611

Ellis, R. (2016). Focus on form: A critical review. Language Teaching Research, 20(3), 405-428. https://doi.org/10.1177\%2F1362168816628627

Farshi, S. S., \& Baghbani, S. D. (2015). The effects of implicit and explicit focus on form on oral accuracy of EFL learners. Theory and Practice in Language Studies, 5(2), 292-297. http://dx.doi.org/10.17507/tpls.0502.08

Gass, S. (2012). Incidental vocabulary learning. Encyclopedia of the Sciences of Learning, 1519-1519. https://doi.org/10.1007/978-1-4419-1428-6_2213

Gheisari, N., \& Yousofi, N. (2016). Iranian pre-university student's retention of collocations: Implicit exposure or explicit instruction. Cogent Education, 3(1), 1-12. https://doi.org/10.1080/2331186X.2016.1184826

Graus, J., \& Coppen, P. A. (2016). Student teacher beliefs on grammar instruction. Language Teaching Research, 20(5), 571-599. https://doi.org/10.1177/1362168815603237

Griffiths, C. (2003). Patterns of language learning strategy use. System, 31(3), 367383. https://doi.org/10.1016/S0346-251X(03)00048-4

Housen, A., \& Pierrard, M. (2005). Investigating instructed second language acquisition. In A. Housen \& M. Pierrard (Eds.), Investigations in instructed second language acquisition (pp. 1-30). Berlin: Mouton de Gruyter.

Hunt, A., \& Beglar, D. (2005). A framework for developing EFL reading vocabulary. Reading in a Foreign Language, 17, 23-59.

Krashen, S., \& Terrell, T. (1983). The natural approach. Hayward, CA: Alemany.

Krashen, S. D. (1994). The input hypothesis and its rivals. In N. C. Ellis (Ed.), Implicit and explicit learning of languages (pp. 45-78). San Diego, CA: Academic Press.

Krashen, S. D., \& Terrell, T. D. (1998). The natural approach: Language acquisition in the classroom. London: Prentice-Hall International.

Lichtman, K. (2013). Developmental comparisons of implicit and explicit language learning. Language Acquisition, 20(2), 93-108. https://doi.org/10.1080/10489223.2013.766740

Ling, Z. (2015). Explicit grammar and implicit grammar teaching for English major students in university. Sino-US English Teaching, 12(8), 556-560. https://doi.org/10.17265/1539-8072/2015.08.002

Long, M. H. (1991). Focus on form: A design feature in language teaching methodology. In K. DeBot, R. Ginsberg, \& C. Kramsch (Eds.), Foreign language research in crosscultural perspective (pp. 39-52). Amsterdam: John Benjamins.

Long, M. H. (1998). Focus on form in task-based language teaching. University of Hawai'i Working Papers in ESL, 16(2), 35-49. 
Long, M. H. (2016). In defense of tasks and TBLT: Nonisssues and real issues. Annual Review of Applied Linguistics, 36, 5-33. https://doi.org/10.1017/S0267190515000057

McMillan, James H. (2008). Educational Research: Fundamental for the Consumer. Fifth Edition. United States of America: Pearson Education, Inc.

Miles, M. B., Huberman, A. M., \& Saldana, J. (2020). Qualitative Data Analysis: A Methods Sourcebook. Thousand Oaks, CA: SAGE.

Murtisari, E. T., Hastuti, G., \& Arsari, R. W. (2019). EFL students' perception of grammar teaching: Isolated or integrated in skill courses? The Asian EFL Journal, 26(6.1), 210.

Nagy, W. E., \& Herman, P. A. (1987). Breadth and depth of vocabulary knowledge: Implications for acquisition and instruction. In M. G. McKeown \& M. E. Curtis (Eds.), The nature of vocabulary acquisition (pp. 19-35). Hillsdale, NJ: Lawrence Erlbaum.

Nazari, N. (2013). The effect of implicit and explicit grammar instruction on learners' achievements in receptive and productive modes. Procedia-Social and Behavioral Sciences, 70, 156-162. https://doi.org/10.1016/j.sbspro.2013.01.051

Poole, A. (2005). Focus on form instruction: Foundations, applications, and criticisms, The Reading Matrix, 5(1), 47-56.

Schmitt, N., \& Zimmerman, C. B. (2002). Derivative word forms: What do learners know? TESOL Quarterly, 36, 145-171. http://dx.doi.org/10.2307/3588328

Scott, V. M. (1989). An empirical study of explicit vs implicit teaching strategies in foreign language instruction. ProQuest Dissertations and Theses, 73(1), 110.

Talley, P. C., \& Hui-Ling, T. (2014). Implicit and explicit teaching of English speaking in the EFL classroom. International Journal of Humanities and Social Science, 4(6), 38-45.

Tammenga-Helmantel, M., Arends, E., \& Canrinus, E. T. (2014). The effectiveness of deductive, inductive, implicit and incidental grammatical instruction in second language classrooms. System, 45(1), 198-210. https://doi.org/10.1016/j.system.2014.06.003

Taylor, D. B., Mraz, M., Nichols, W. D., Rickelman, R. J., \& Wood, K. D. (2009). Using explicit instruction to promote vocabulary learning for struggling readers. Reading and Writing Quarterly, 25(2-3), 205-220. https://doi.org/10.1080/10573560802683663

Uysal, N. D., \& Yavuz, F. (2015). Pre-service teachers' attitudes towards grammar teaching, 191, 1828-1832. https://doi.org/10.1016/j.sbspro.2015.04.353

Yin, R. K. (2003). Case study research: Design and methods. United States of America: Sage Publications. 